2015

\title{
The European Commission's Push to Consolidate and Expand ISDS: An Assessment of the Proposed Canada-Europe CETA and Europe-Singapore FTA
}

Gus Van Harten

Osgoode Hall Law School of York University, gvanharten@osgoode.yorku.ca

Follow this and additional works at: http:// digitalcommons.osgoode.yorku.ca/olsrps

Part of the Dispute Resolution and Arbitration Commons, and the International Law Commons

\section{Recommended Citation}

Van Harten, Gus, "The European Commission's Push to Consolidate and Expand ISDS: An Assessment of the Proposed CanadaEurope CETA and Europe-Singapore FTA" (2015). Osgoode Legal Studies Research Paper Series. 105.

http://digitalcommons.osgoode.yorku.ca/olsrps/105 
Osgoode Legal Studies Research Paper No. 23

Vol. 11/ Issue. 05/ (2015)

\title{
The European Commission's push to consolidate and expand ISDS: An assessment of the proposed Canada-Europe CETA and Europe- Singapore FTA
}

\author{
Gus Van Harten
}

\begin{abstract}
:
The purpose of this paper is to evaluate the European Commission's approach to investorstate dispute settlement (ISDS) in the proposed CETA with Canada and FTA with Singapore. The text on ISDS in both agreements is evaluated according to general criteria of independence, fairness, openness, and balance. The main conclusion reached is that there is no significant difference between the CETA and FTA when it comes to ISDS. With the qualified exception of the criterion of openness, both agreements fall well short of satisfying the criteria. As such, neither agreement offers a significant improvement on the U.S. model of ISDS and, in some respects, the Commission's approach would make things worse, especially on the criterion of balance. Viewed alongside the TTIP, the CETA and FTA should be understood as an effort by the Commission to expand and lock in a deeply flawed system of dispute resolution-premised on the special privileging and subsidizing of large companies and very wealthy individuals, with lucrative returns also for ISDS lawyers and arbitrators-so that it covers most of the world economy.
\end{abstract}

\section{Keywords:}

CETA, FTA, TTIP, ISDS, European Commission, investment, arbitration

\section{Author(s):}

Gus Van Harten

Associate Professor

Osgoode Hall Law School

York University, Toronto

E: gvanharten@osgoode.yorku.ca 
The European Commission's push to consolidate and expand ISDS:

An assessment of the proposed Canada-Europe CETA and Europe-Singapore FTA

\author{
Working Paper \\ Gus Van Harten \\ Associate Professor \\ Osgoode Hall Law School \\ gvanharten@osgoode.yorku.ca
}

June 2015

\title{
I. Introduction
}

The European Union is currently pushing investor-state dispute settlement (ISDS) in three proposed trade agreements. The most significant is the least mature: the proposed Europe-U.S. Transatlantic Trade and Investment Partnership (TTIP), for which no public text is available. ${ }^{1}$ For the other two agreements, a public text is available, although the agreements have not been signed or ratified. These are the proposed Canada-Europe Comprehensive Economic and Trade Agreement (CETA) ${ }^{2}$ and the proposed Europe-Singapore Free Trade Agreement (FTA). ${ }^{3}$

The purpose of this paper is to evaluate the CETA and FTA models of ISDS based on general criteria of independence, fairness, openness, and balance. The main conclusion reached is that there is no significant difference between the CETA and FTA when it comes to ISDS. With the qualified exception of the criterion of openness, both agreements fall well short of satisfying the criteria. As such, neither agreement offers a significant improvement on the U.S. model of ISDS and, in some respects, the Commission's approach would make things worse, especially on the criterion of balance.

The CETA and FTA also provide evidence to assess the extent to which the Commission would accept the U.S. model of ISDS in the TTIP. On this issue, both agreements demonstrate that the Commission is prepared to accept the U.S. model almost entirely, especially in the form adopted since the early 2000s. Where there are variations from the U.S. model in the CETA and FTA, the Commission can be expected to shift further toward the U.S. model in the TTIP due to the obviously greater bargaining power of the U.S. relative to Canada and Singapore.

\footnotetext{
${ }^{1}$ European Commission, "Public consultation on modalities for investment protection and ISDS in TTIP" (undated) [TTIP consultation text], available online: European Commission http://trade.ec.europa.eu/doclib/docs/2014/march/tradoc 152280.pdf (last accessed 8 October 2014); all page number references are to the online pdf version in which the pages are not numbered.

2 Canada-European Union: Comprehensive Economic and Trade Agreement (CETA): Consolidated CETA Text, available online: Department of Foreign Affairs and International Trade (Canada) http://www.international.gc.ca/trade-agreements-accords-commerciaux/agr-acc/ceta-aecg/texttexte/toc-tdm.aspx?lang=eng (last accessed 8 October 2014).

3 Text of the EU-Singapore Free Trade Agreement (FTA), available online: European Commission http://trade.ec.europa.eu/doclib/press/index.cfm?id=961 (last accessed 1 June 2015).
} 
Thus, the CETA and FTA, viewed alongside the TTIP negotiations, should be understood as an effort by the Commission to expand massively the scope of ISDS.4 For instance, using the U.S. economy as a proxy, TTIP alone would extend ISDS coverage of international investment flows by about 300 per cent compared to current ISDS coverage based on existing treaties. That is, TTIP would cover 50-60\% of investment flows in and out of the U.S. whereas current treaties of the U.S. cover $15-20 \%$ of such investment flows. Besides TTIP, a few other treaties pursued by the Commission or the U.S.--the Trans-Pacific Partnership, EU-China investment treaty, and U.S.-China investment treaty- would expand coverage of ISDS to the great majority of investment flows worldwide.

\section{Evaluation of the CETA and FTA}

In this section, the CETA and FTA models of ISDS are evaluated against five criteria, each reflecting a core concern about ISDS-or, more precisely, the arbitration mechanism at the heart of ISDS-to decide the legality of sovereign conduct and re-allocate public money to foreign investors. ${ }^{5}$ The first three criteria-independence, fairness, and openness-reflect key elements of a judicial process, particularly a judicial process used for the final resolution of disputes about sovereign conduct and public funds. ${ }^{6}$ The remaining criterion-balance-relates to the allocation of substantive rights and responsibilities in treaties that authorize ISDS.

\section{A. Independence}

To be independent in the manner of a court, ISDS would need to incorporate the conventional institutional safeguards of judicial independence. For example, it would need to ensure:

(a) security of tenure for the adjudicator;

(b) a set salary for the adjudicator;

(c) an objective method of case assignment such as lottery or rotation;

(d) a prohibition on outside lawyering by the adjudicator; and

(e) a judicial process to resolve conflict-of-interest claims.

\footnotetext{
4 These approximate figures were calculated based on existing investment treaty coverage of country-bycountry inward and outward FDI flows for the U.S. in 2012 from the data provided in Organization for Economic Cooperation and Development (OECD), "StatExtracts: FDI flows by partner country", available online: http://stats.oecd.org/Index.aspx?DataSetCode=FDI_FLOW_PARTNER. The figures do not account for the possibility of forum-shopping by foreign investors which is difficult to measure and handled in different ways by arbitrators and existing treaties, but which could expand existing ISDS coverage.

5 G. Van Harten, "Investment Treaty Arbitration, Procedural Fairness, and the Rule of Law" in SW Schill (ed) International Investment Law and Comparative Public Law (Oxford: OUP, 2010); G Van Harten, Investment Treaty Arbitration and Public Law (Oxford: OUP, 2007) 159-75.

${ }^{6}$ For an elaboration, see G. Van Harten, "The EC and UNCTAD reform agendas: Do they ensure independence, openness, and fairness in investor-state arbitration?” in M. Krajewski and S. Hindelang (eds) Shifting Paradigms in International Investment Law: More Balanced, Less Isolated, Increasingly Diversified (under submission to Oxford University Press).
} 
These institutional safeguards are standard features of domestic courts and other international tribunals that resolve disputes concerning the legality of sovereign conduct. ISDS does not incorporate these safeguards, allowing instead for:

(a) case-by-case appointment of adjudicators;

(b) case-by-case (i.e. for-profit) payment of adjudicators;

(c) executive control over default case assignments for adjudicators;

(d) allowances for outside legal work in ISDS by adjudicators; and

(e) executive control over conflict-of-interest challenges against adjudicators.

Neither the CETA nor the FTA would alter this structure of ISDS. As a result, both agreements fail to address the lack of independence in ISDS, contemplating instead a process that gives rise to reasonable suspicions of adjudicative bias that would taint all outcomes in ISDS.7

These suspicions of bias can operate in favour of a country, a foreign investor, or other parties, depending on the circumstances. For example, because ISDS arbitrators are appointed case-bycase and paid (lucratively) by the appointment, all of the arbitrators depend financially on whoever can trigger an arbitration. Under investment treaties, only foreign investors have this triggering power and only states must pay compensation for violations of the treaty. Thus, ISDS arbitrators have an evident incentive to favour foreign investors, especially those most able to bring claims. ${ }^{8}$

Similarly, an ISDS arbitrator-who lacks secure tenure and is interested in future appointments-is necessarily dependent on whoever has the default power over the appointment of arbitrators when a foreign investor and state do not agree on the presiding arbitrator or when either does not appoint its own arbitrator. On this issue, the CETA and FTA give default appointing authority to the Secretary General of the World Bank's International Centre for Settlement of Investment Disputes (ICSID). ${ }^{9}$ The ICSID Secretary-General is an executive official not a judicial actor. It is fundamentally inconsistent with judicial independence to allow an executive official to choose who will decide a case after learning who has sued whom and in what context. This structure allows the executive official to ensure that sensitive cases are kept in safe hands, according to the politics of the claim.

The most significant step in the CETA and FTA concerning the lack of independence in ISDS is the proposed incorporation of a code of conduct for ISDS arbitrators. ${ }^{10}$ Even so, this is a very limited step due to the form taken by the code, which would not incorporate any of the conventional safeguards mentioned above. The code would not even preclude ISDS arbitrators from working on the side as ISDS lawyers, which is an obvious contribution a code of conduct could make. Further, the code would be policed by an executive official based on a process of complaints filed by disputing parties. ${ }^{11}$ This is inadequate in various ways. For example, it

7 Ibid.

8 Ibid.

9 CETA (n 2 above) Article X.25(2) and (3); FTA (n 3 above) Article 9.21(2).

${ }_{10}$ CETA (n 2 above) Article X.42(2); FTA (n 3 above) Annex 9-B.

${ }^{11}$ CETA (n 2 above) Article X.25(10); FTA (n 3 above) Article 9.21(10). 
assumes that the disputing parties would be able to uncover the outside counsel work of an ISDS arbitrator, even though ISDS arbitrations are in some cases entirely secret. ${ }^{12}$ Unless an arbitrator declares a potential conflict, therefore, the affected disputing party may have no way of knowing about the arbitrator's role as counsel.

The CETA and FTA would come closest to addressing some aspects of the lack of independence in ISDS by moving tentatively toward a roster of arbitrators. ${ }^{13}$ A set roster of adjudicators could be a positive step toward a judicial process. However, the roster in the CETA and FTA is clearly insufficient because: (a) the roster would not apply to all arbitrators appointed to the tribunal; (b) an executive official retains the power to choose who is appointed from the roster case-bycase; and (c) the executive official would be able to appoint arbitrators from outside of the roster if the states parties to the treaty did not agree on the roster's membership. ${ }^{14}$ For two decades, this last loophole has foiled the similar roster in NAFTA investor-state arbitration. ${ }^{15}$

The failure to ensure judicial independence in ISDS is a fundamental flaw in the CETA and FTA. Without the basic safeguards of judicial independence, ISDS outcomes as a whole will lack integrity regardless of the treaty text or the arbitrators' goodwill. In essence, the CETA and FTA allow foreign investors to take final adjudicative power from courts and give it to a small cadre of ISDS arbitrators and executive officials, none of whom are institutionally independent in the manner of a judge.

\section{B. Fairness}

ISDS arbitration is arguably unfair for many reasons but the most precise one is procedural. To be fair, an adjudicative process must allow any party whose rights or interests are affected by the adjudication to have full standing in the process. This is a straightforward and longstanding principle of fairness. ${ }^{16}$ If all affected parties could not have standing in the process, an adjudicator would not be required (and in a position) to hear all sides to the dispute.

ISDS does not ensure this basic right for all affected parties. For that reason, it is unfair. Instead, ISDS allows a right of full standing for claimant investors and respondent governments only. ${ }^{17}$ No one else whose rights or interests are affected can obtain such rights, regardless of the extent to which their rights or interests are affected and regardless of their perspective. ${ }^{18}$

\footnotetext{
${ }^{12}$ The problem of complete secrecy appears most acute in arbitration under the International Chamber of Commerce (ICC) arbitration rules. G. Van Harten, "A total lack of transparency" Canadian Lawyer (24 October 2011).

13 TTIP consultation text (n 1 above) 13.

${ }_{14}$ CETA (n 2 above) Article X.25 (2) to (4); FTA (n 3 above) Article 9.21 (2) and (4).

15 North American Free Trade Agreement (NAFTA) (17 December 1992; 32 ILM 296 and 605; entered into force 1 January 1994), Article 1124(4).

${ }^{16}$ G. Van Harten, G. Heckman, D.J. Mullan, J. Promislow, Administrative Law - Cases, Text, and Materials, $7^{\text {th }}$ edn (Toronto: Emond, 2015) 73-74.

${ }_{17}$ CETA (n 2 above), Article X.3; FTA (n 3 above) Article 9.14(2)(a) (definition of "disputing parties").

${ }^{18}$ For an indication of cases in which outside parties were affected by an ISDS proceeding, see Van Harten (n 6 above).
} 
In response to this problem-and drawing on the U.S. model of ISDS since the early 2000s-the CETA and FTA allow limited third-party (also known as amicus) representation in ISDS. ${ }^{19}$ This "reform" falls well short of what is required for basic fairness in ISDS. Amicus representation does not require an ISDS tribunal to give full standing to all persons with a direct interest in the proceeding. ${ }^{20}$ Amicus representation merely lets a party take part in proceedings in a limited way, to the extent and as authorized by the arbitrators. ${ }^{21}$ For ISDS to be fair, it would need to provide an automatic right of full standing for all affected parties. ${ }^{22}$

As a result, the Commission's approach to ISDS continues to allow arbitrators to make decisions that may affect other parties-whether private actors or public entities-without hearing from them. This unfairness can be addressed only by requiring public notice of all ISDS claims and by allowing time for other affected parties to apply, in a judicial process, for full standing.

\section{Openness}

Courts are open in the sense that all documents and hearings before the court are presumptively public, subject to specifically-enumerated and judicially-approved exceptions. Courts are open to allow for public accountability and to support the independence and fairness of the court. In contrast, ISDS is not fully open and, in some instances, it is completely closed because even the mere existence of the arbitration is kept secret.

The lack of openness in ISDS has been criticized since at last the late 1990s when the foreign investor lawsuits began to explode, most notably under NAFTA and the Energy Charter Treaty. ${ }^{23}$ In the case of NAFTA, the Canadian, Mexican, and U.S. governments responded by releasing a joint interpretation of NAFTA in 2001 that made clear that each government could disclosure ISDS documents and, subsequently, by putting provisions on openness in new trade and investment agreements. ${ }^{24}$ Similarly, in 2010, UNCITRAL issued new transparency rules for

\footnotetext{
19 CETA (n 2 above) Article X-35(1)(b)(ii); FTA (n 3 above) Annex 9-C (Article 3).

${ }^{20} \mathrm{P}$ Wieland, "Why the Amicus Curia Institution is Ill-suited to address Indigenous Peoples' Rights before Investor-State Arbitration Tribunals: Glamis Gold and the Right of Intervention" (2011) 3 Trade, Law \& Dev't 334, 344-5 and 359-60; N. Blackaby and C. Richard, "Amicus Curiae: A Panacea for Legitimacy in Investment Arbitration?" in M Waibel et al (eds) The Backlash against Investment Arbitration (Austin: Wolters Kluwer, 2010) 259-66.

${ }^{21}$ In actual arbitrations, amicus representation has been used rarely and with significant restrictions; Wieland, ibid, 341-4.

${ }^{22}$ E Levine, "Amicus Curiae in International Investment Arbitration: The Implications of an Increase in Third-Party Participation” (2012) 29 Berkeley J Int'l L 200, 208-14; A Salazar, 'Defragmenting International Investment Law to Protect Citizen-Consumers: The Role of Amici Curiae and Public Interest Groups' (Osgoode Hall Law School, Comparative Research in Law \& Political Economy Research Paper No 6/2013, 2013) 4-8.

23 G. Van Harten, Sold Down the Yangtze: Canada's Lopsided Investment Deal with China (IIAPP/ selfpublished, 2015) chapters 11 and 21.

24 Free Trade Commission (NAFTA), Notes of Interpretation of Certain Chapter 11 Provisions (31 July 2001), online: Government of Canada http://www.international.gc.ca/trade-agreements-accordscommerciaux/topics-domaines/disp-diff/NAFTA-Interpr.aspx (last accessed June 1, 2015). Canada recently pulled back from this position in the Canada-China BIT by permitting the host state to an arbitration claim to withhold all documents other than awards from disclosure where it decides this is in the public interest. Agreement between the Government of Canada and the Government of the People's
} 
ISDS pursuant to the UNCITRAL arbitration rules, although these reforms were not extended to new ISDS arbitrations under the many existing treaties that authorize ISDS under the UNCITRAL rules. ${ }^{25}$

Allowances for secrecy, at the option of a disputing party, may be appropriate in commercial arbitration where the implications of a dispute are often limited to the disputing parties. Yet, such secrecy are is fundamentally misplaced in investment treaty arbitration where the arbitrators regularly review the decisions of legislatures, governments, and courts in matters of public interest and where they can award massive amounts of compensation from public funds. These are among the highest powers that any adjudicator can wield. ${ }^{26}$ To support the role of adjudication in a democracy, such powers must be exercised publicly, subject to judiciallyapproved exceptions.

The CETA and FTA go a long way to addressing the lack of openness in ISDS. Following the U.S. model since the early 2000s, both agreements require ISDS documents and hearings to be made public. ${ }^{27}$ The requirement for publication of documents, in particular, is close to comprehensive in that it includes a foreign investor's original request for consultation or arbitration, all the submissions of the parties, and all tribunal decisions. ${ }^{28}$

Yet, the CETA and FTA still have limitations in terms of openness. Most importantly, it is up to ISDS arbitrators, not judges, to decide whether documents or hearings should be kept secret. ${ }^{29}$ Also, under the CETA and FTA, a foreign investor could threaten a claim-and a settlement may be reached involving payment of public money and or changes to legislative, government, or judicial decisions-entirely in secret. To address this issue, the CETA and FTA would need to make clear that the fact and terms of a settlement arrived at by a state, following an invocation of the treaty, would be reported publicly.

\section{Balance}

I shift now from the process of ISDS to its structural design, referring in particular to the allocation of substantive rights and responsibilities. To be balanced, I suggest that ISDS would need to affirm the right to regulate of states alongside the elaborate rights and protections that it gives to foreign investors. Further, ISDS would need to incorporate responsibilities for foreign investors that are actionable in the manner of their rights. This is a formal or thin version of the

Republic of China for the Promotion and Reciprocal Protection of Investments, signed 9 September 2012, entered in force 1 October 2014, online: http://www.international.gc.ca/trade-agreements-accordscommerciaux/agr-acc/fipa-apie/china-text-chine.aspx?lang=eng (last accessed 12 October 2014), Article 28(1).

25 UNCITRAL, Rules on Transparency in Treaty-based Investor-State Arbitration (New York: United Nations, 2014).

${ }_{26}$ G. Van Harten, Investment Treaty Arbitration and Public Law (Oxford: Oxford University Press, 2007) chapter 3 .

${ }^{27}$ CETA (n 5 above) Article X.33.

${ }^{28}$ CETA (n 2 above) Article X.33(1), which incorporates the UNCITRAL Rules on Transparency in Treaty-based Investor-State Arbitration (above n 26), as supplemented by CETA Article X.33(2).

${ }_{29}$ CETA (n 5 above) Article X.33 (4) to (5); FTA, Annex 9-C, Article 4(7) and (11). 
concept of balance because, with the exception of the clarity of any affirmation of the state's right to regulate, it does not engage the issue of the appropriate content and extent of foreign investors' rights and responsibilities. $3^{30}$

In the CETA and FTA, and virtually as a general rule under investment treaties, ISDS is imbalanced. On the one hand, it delivers a suite of wide-ranging and highly-enforceable foreign investor rights and corresponding responsibilities for countries. On the other hand, it lacks a clear affirmation of the state's right to regulate and lacks any substantive and actionable responsibilities for foreign investors.

The responsibilities assumed by states in ISDS are wide-ranging. They include the responsibilities to submit to ISDS arbitrator power and pay compensation as ordered by the arbitrators, where a majority of the arbitrators decide that the state did not treat a foreign investor fairly and equitably, did not pay sufficient compensation for a direct expropriation or general regulation, discriminated in favour of domestic investors, or inappropriately limited transfers of capital, for example. ${ }^{31}$ Yet, the responsibilities are rarely if ever accompanied by a clear and unqualified affirmation of the state's general right to exercise its regulatory role in relation to foreign investors. ${ }^{2}$

Investment treaties could affirm this general right of the state alongside the state's responsibilities. That is, the right could be stated clearly in the treaty, without broad limitations, and applied to all of the state's obligations to protect foreign investors. ${ }^{33}$ However, In the CETA and FTA investment chapters, the right to regulate is not stated at all, let alone clearly as a right of the state.

Instead, in the case of the CETA, the right to regulate is mentioned in an aspirational statement in the preamble and in two other chapters (on labour and the environment, thus preserving the state's flexibility in the face of international labour and environmental standards) not including the investment chapter. ${ }^{34}$ In the case of the FTA, it is mentioned only in two chapters (on services and the environment). 35 This approach to the right to regulate actually undermines the reliability of that right in the investment chapter, if the right is thought to be implicit there somehow, because it creates an inference that the parties to the treaty intended to make the right substantive and effective only in the chapters of the agreement that incorporate it clearly

$3^{30}$ For a cautious approach to the issue of foreign investor responsibilities, see P.T. Muchlinski, Multinational Enterprises \& the Law, 2d edn (Oxford: OUP, 2007), chapter 3.

${ }^{31}$ e.g. CETA (n 2 above) Articles X.6, X.9, X.11, and X.12.

${ }^{2}$ J.A. VanDuzer, P. Simons, and G. Mayeda, Integrating Sustainable Development into International

Investment Agreements: A Guide for Developing Countries (London: Commonwealth Secretariat, 2012) 287-398.

33 e.g. Convention for the Protection of Human Rights and Fundamental Freedoms (the European Convention on Human Rights [ECHR]) (4 November 1950; Eur TS 5, 213 UNTS 222; entered into force 3 September 1953); Final Act of the United Nations Conference on Trade and Employment: Havana Charter for an International Trade Organization (the Havana Charter), UN Conference on Trade and Employment, UN Doc 1948 II.D.4.1 (1948).

34 e.g. CETA (n 2 above) Preamble, Chapter 24 (Article 2), and Chapter 25 (Article X.4).

35 FTA (n 3 above) Chapter 8 (Articles 8.1(2)) and Chapter 13 (Article 13.2). 
and expressly. Simply, the CETA and FTA do not balance the right to regulate against the state's responsibilities to protect foreign investors.

Nevertheless, the Commission has claimed that the CETA and FTA safeguard the right to regulate by a series of textual clarifications, drawn mainly from the U.S. model of ISDS since the early 2000s. ${ }^{36}$ For example, 37 the CETA and FTA have moderating language for one foreign investor right: the right to (generous) compensation for any general regulation treated by the arbitrators as an indirect expropriation..$^{8}$ This language supports, to an uncertain degree, the state's regulatory flexibility in relation to its obligation to pay compensation for expropriation, but is also limited for a range of reasons discussed in more detail elsewhere. 39 For example, the moderating language does not apply to all of the foreign investor rights in the treaty, including the one that has been used most frequently, to date, by arbitrators in ordering compensation for foreign investors. Also, the Commission's approach keeps interpretive power in the hands of ISDS arbitrators who have only very rarely accepted a general balancing of foreign investor rights against the state's right to regulate or the rights of other actors. $4^{\circ}$ If the Commission wanted to affirm the right to regulate, it would need to do so clearly, for all the treaty's obligations for states and in all areas of decision-making. That is has not done so speaks volumes.

I turn now to the issue of foreign investor responsibilities. While foreign investors enjoy a wide range of powerful rights in ISDS, virtually as a rule they have no corresponding and actionable responsibilities to respect international standards. There are different ways to address this imbalance in the allocation of rights and responsibilities. For example, as a limited starting point, the treaties could allow states to bring claims against a foreign investor that initiated a claim in circumstances where the investor has not met a basic standard of appropriate conduct. This would still not be formally balanced because it would not give the state a right, alongside that of foreign investors, to initiate an ISDS proceeding. Also, it would not give any rights to private parties who are harmed seriously by a foreign investor and denied justice in the host state's courts. Yet, there is no sign that even this modest step has been pursued by the Commission or any other Western governmental actor playing a major role in pushing for investment treaties.

Similarly, in the CETA and FTA, there is no indication of foreign investors being held to actionable responsibilities, as a balance against their elaborate rights. The resulting imbalance is

${ }^{36}$ TTIP consultation text (n 1 above) 2.

37 The other main examples relate to the CETA and FTA's language on fair and equitable treatment, which is discussed in more detail below, and to the use of exceptions, reservations, and carve-outs. For a discussion of why the Commission's approach to these issues is dangerous or misleading, from the perspective of balancing the state's right to regulate, see G. Van Harten, "Reforming the System of International Investment Dispute Settlement" in C.L. Lim (ed) Alternative Visions in the International Law on Foreign Investment: Essays in Honour of M. Sornarajah (Cambridge: Cambridge University Press, forthcoming).

${ }^{38}$ CETA (n 2 above) Article X.11.

39 e.g. Van Harten (n 23 above) 93-95.

40 Van Harten, Sovereign Choices and Sovereign Constraints (Oxford: Oxford University Press, 2013) 89104. 
especially acute because of the lack of a requirement in either agreement for foreign investors to go to a state's domestic courts before resorting to ISDS. The duty to resort to local remedies, where they offer justice and are reasonably-available, applies customarily in international law and in other international courts and tribunals where individuals can bring claims against a state. ${ }^{41}$ The Commission's approach-building on the unfortunate Western European legacy of imbalanced investment treaties-allows foreign investors to bring ISDS claims without resorting to domestic courts, regardless of whether the courts in question offer justice. In turn, the Commission's approach implies, absurdly, that domestic courts fail to offer justice in all countries. Likewise, this approach implies, also absurdly, that ISDS is independent and fair in the manner of a court, which it clearly is not.

Why should foreign investors be relieved of the customary duty to go to domestic courts, without foreign investors even having to show that the courts do not offer justice? One might worry that domestic courts could take too long or are otherwise inadequate to protect foreign investors. If that is a pressing concern, then why not replace courts with arbitrators for everyone? Clearly, others-whether foreigners or nationals in a country-may suffer as much or indeed far more than a foreign investor. To pose the question reveals the radical proposition lying behind ISDS: the replacement of domestic courts with an exceptionally-powerful adjudicative system available to foreign investors only. In short, the Commission's approach in the CETA and FTA, reflecting the U.S. model of ISDS, establishes that foreign investors-unlike anyone else-should have access to ISDS and then, on top of it, that they should be excused from having to show that domestic courts are inadequate in any way.

These issues also raise broader questions about the balancing of rights and responsibilities. In particular, what if domestic courts are inadequate to protect victims of foreign investors? One can imagine scenarios in which someone may suffer greatly because of the misconduct of a foreign investor. Yet such actors would be limited to domestic courts with no right to initiate an international claim and to obtain public compensation. A quick example should hammer home the imbalance. In the era of ISDS, a foreign national who is tortured by state officials cannot bring an international claim against the state, at least without going first to domestic courts. ${ }^{42}$ However, the foreign national could bring an ISDS claim if he or she owned assets in the stateand qualified as a foreign investor-but in that case only to the extent that the torture affected his or her position as an asset owner not a human being. In contrast, if a foreign investor's personnel were to torture its domestic employees with the state's collaboration, none of the employees could bring an international claim against the company or its officers. Likewise, the employees could not bring a claim against the state, for failing to protect them without going to domestic courts first.

\footnotetext{
${ }^{41}$ e.g. S. D'Ascoli and K.M. Scherr, "The Rule of Prior Exhaustion of Local Remedies in the International Law Doctrine and its Application in the Specific Context of Human Rights Protection” European University Institute (EUI) Working Paper LAW No. 2007/o2 (2007).

$4^{2}$ e.g. Convention against Torture and Other Cruel, Inhuman or Degrading Treatment or Punishment, GA Res. 39/46, annex, 39 UN GAOR Supp. (No. 51) at 197, UN Doc. A/39/51 (1984); 1465 UNTS 85 (entered into force 26 June 1987), Articles 21(c) and 22(4)(b).
} 
This set-up is a profoundly imbalanced elevation of foreign investors' rights and protections over everyone else's. The CETA and the FTA endorse the arrangement by not incorporating any actionable responsibilities for foreign investors. They do not even incorporate a duty to exhaust local remedies before the foreign investor can bring an ISDS claim asserting its powerful rights.

\section{Micro-level variations}

In this section, I highlight some significant variations between the CETA and FTA. By significant, I mean variations that appear to mark an ambiguity in the Commission's ISDS preferences. As highlighted in the discussion, some of the variations between the CETA and FTA are also distinct from the U.S. model of ISDS. The assessment is intended to capture most such variations, but it is not a comprehensive analysis of all of the significant variations between the CETA and FTA or between these agreements and the U.S. model.

A. Foreign investor rights

1. Definition of "investment"

a. Breadth of the definition

The CETA and FTA define investment in essentially the same way. Both definitions are wideranging, as typical in bilateral investment treaties and trade agreements allowing for ISDS, such as NAFTA. Thus, both agreements focus on protecting asset owners in general. They are not limited simply to investment in the sense of capital committed to a risky venture in the expectation of profit.

The FTA definition ${ }^{43}$ is somewhat broader on paper than the CETA definition ${ }^{44}$ because it specifically includes "goodwill" and to "licenses, authorizations, permits, and similar rights conferred pursuant to applicable domestic law, including any concessions to search for, cultivate, extract or exploit natural resources"; on the latter element, the CETA has a similar clause that refers to concessions and contracts.

Based on the record of ISDS awards, these differences in language are minor because other aspects of the definition of investment lend themselves to capturing broad notions of asset ownership. For example, the CETA definition includes "[e]very kind of asset that an investor owns or controls, directly or indirectly" and the FTA definition includes "every kind of asset which is owned, directly or indirectly or controlled, directly or indirectly by investors".

b. Pro-investor approach to the Salini criteria

43 FTA (n 3 above) Article 9.1.

44 CETA (n 2 above) Article X.3. 
Interestingly, the CETA and FTA both qualify the definition of investment by incorporating, as an optional reference for an ISDS tribunal, aspects of the so-called Salini criteria. 45 These criteria were adopted in early ISDS awards and applied by some ISDS tribunals as a way to orient and limit the concept of investment in investment treaties.

In particular, the CETA applies only to an asset: "that has the characteristics of an investment, which include a certain duration and other characteristics such as the commitment of capital or other resources, the expectation of gain or profit, or the assumption of risk". ${ }^{6}$ Similarly, the FTA applies only to an asset: "that has the characteristics of an investment, including such characteristics as the commitment of capital or other resources, the expectation of gain or profit, the assumption of risk, or a certain duration". ${ }^{47}$ A significant difference between these definitions is that the CETA appears to require only one mandatory characteristic-"a certain duration"-and lays out the other three characteristics as examples for ISDS arbitrators to consider. The FTA is even more liberal because it lists all four characteristics merely as examples for ISDS arbitrators to consider.

Most importantly, the CETA and FTA both move away from past ISDS awards that applied these characteristics-i.e. the Salini criteria-as mandatory and cumulative aspects of the concept of investment. Also, the CETA and FTA would drop one of the Salini criteria: the requirement that an asset, to qualify as an investment, must contribute to the development of the host country's economy.

By altering the Salini criteria in these ways, the CETA and the FTA cast aside even the limited constraints on the concept of investment, as applied by some ISDS arbitrators. In doing so, they evidently endorse the preference of some ISDS arbitrators not to apply the Salini criteria, or to treat the criteria as optional guidelines rather than mandatory requirements. ${ }^{48}$ In either case, the CETA and FTA endorse an approach that obviously favours claimants. In other words, the Commission, Singapore, and Canada have codified the investor-friendly approach to the definition of investment that has emerged from the record of ISDS awards.

\section{Fair and Equitable Treatment}

The most important lesson to draw from the Commission's approach to fair and equitable treatment in the CETA and FTA is that the Commission appears committed to expanding ISDS arbitrator power, even compared to the U.S. approach to this foreign investor right. As outlined below, the codification of some of the most expansive concepts imported by arbitrators into the concept of fair and equitable treatment goes beyond the U.S. model or, for that matter, Canada's past approach. 49 Thus, it appears that the Commission was the driver of the change.

\footnotetext{
45 O.E. García-Bolívar, "Defining an ICSID Investment: Why Economic Development Should be the Core Element” Investment Treaty News (13 April 2012).

${ }^{46}$ CETA (n 2 above) Article X.3.

47 FTA (n 3 above) Article 9.1(1).

48 García-Bolívar (n 45 above).

49 Canada's treaties providing for ISDS have followed the U.S. approach by clarifying, since the early 2000 shen the issue was raised in response to early NAFTA awards, that fair and equitable treatment is
} 


\section{a. Relatively expansive approach}

The most widely-invoked right of foreign investors under investment treaties is "fair and equitable treatment". $5^{\circ}$ This concept has been given a range of different readings-often very expansive-by ISDS arbitrators..$^{1}$

In the U.S. model of ISDS, as adopted since the early 2000s, an attempt was made to rein in ISDS arbitrators by limiting the concept to the meaning of the minimum standard of treatment in customary international law. ${ }^{2}$ This attempt has had only limited success. Success has been limited because ISDS arbitrators overwhelmingly adopted a relaxed standard of proof for foreign investors, when they are required to establish an evolution of the customary minimum standard, by relieving them of the usual onus to provide evidence of state practice and opinio juris in order to establish an evolution of customary international law.53

The CETA and FTA are more expansive in their approach to fair and equitable treatment than the U.S. model of ISDS. Neither agreement clearly restricts ISDS arbitrators to applying the conventionally-understood concept of the minimum standard in customary international law. Instead, they allow ISDS arbitrators to apply some of the novel concepts that were read into the concept of fair and equitable treatment by ISDS arbitrators in numerous decisions since the foreign investor lawsuits began to explode in the late 1990s. ${ }^{44}$ Thus, the CETA and FTA in effect codify core features of the arbitrators' adventurous approach to foreign investor rights.

This aspect of the CETA and FTA is perhaps the most important issue on which the Commission's approach differs from the U.S. model. In its approach to fair and equitable treatment, the Commission clearly has gone further in favour of foreign investor rights than the U.S. model.

b. Lack of clarity in the closure of the list of components

Additionally, the CETA and FTA definitions of fair and equitable treatment are both based on a list of components. ${ }^{55}$ Any of the components on the list may give rise to a breach of fair and equitable treatment. In both agreements, the list is essentially the same; both agreements include the components of denial of justice, fundamental breach of due process, manifest

limited to the meaning of the minimum standard of treatment in customary international law. That said, in some of Canada's treaties, this clarifying language is undermined by a most-favoured-nation treatment loophole. G. Van Harten, "The Canada-China FIPPA: Its Uniqueness and Non-Reciprocity” (2013) 51 Canadian Yearbook of International Law 3, 27-34 and Annex 1.

$5^{\circ}$ Van Harten (n 40 above) 101-103.

${ }^{51}$ Ibid, 102.

52 e.g. Dominican Republic-Central America-United States Free Trade Agreement, 19 USCS S. 4011 (2005) (CAFTA), Article 10.5(2).

53 M. Porterfield, "A Distinction Without a Difference? The Interpretation of Fair and Equitable Treatment Under Customary International Law by Investment Tribunals” Investment Treaty News (22 March 2013). 54 Van Harten (n 40 above) 102.

55 CETA (n 2 above) Article X.9; FTA (n 3 above) Article 9.4. 
arbitrariness, and abusive or bad faith conduct. The CETA adds to this list the component of targeted discrimination on manifestly wrongful grounds.

The use of a list to lay out components of the foreign investor right to fair and equitable treatment has the potential to limit the meaning given to that right by ISDS arbitrators. However, the CETA and, to an apparently lesser extent the FTA, have a significant loophole because they do not make crystal clear that the list is closed. For example, the CETA does not say that the right to fair and equitable treatment is breached "only" when one of the components on the list is breached..$^{6}$ This lack of clarity gives an opportunity for ISDS arbitrators to continue their adventurous approach to the concept of fair and equitable treatment by adding new components to the list.

The FTA has somewhat stronger language to limit the open-endedness of the list. The FTA says that treatment not included in the list can constitute a breach of fair and equitable treatment "where the Parties [to the treaty] have so agreed". 57 By comparison, the equivalent clause in the CETA adds to the list of illustrative breaches "any further elements of the fair and equitable treatment obligation adopted by the Parties". ${ }^{8}$ Thus, the CETA and FTA both leave interpretive room for arbitrators to incorporate new components to the concept of fair and equitable treatment, although the FTA is somewhat clearer in conveying that arbitrators are expected to apply the concept only as defined in the list.

c. Codification of the novel component of "legitimate expectations"

On the other hand, the FTA is somewhat more expansive than the CETA in a different aspect of its approach to fair and equitable treatment. The FTA includes one of the most novel concepts read into the right to fair and equitable treatment by ISDS arbitrators. The concept is "legitimate expectations", which has been used widely by arbitrators to condemn countries and order compensation for foreign investors.

The FTA is more expansive than the CETA in this respect because it puts the concept of legitimate expectations on the list of components of fair and equitable treatment.59 In contrast, the CETA allows the arbitrators to take into account the concept of legitimate expectations when applying other components of fair and equitable treatment. ${ }^{60}$ Both agreements give the arbitrators a licence in the treaty itself to rely on the concept of legitimate expectations, but the FTA appears to do so more broadly than the CETA.

\section{Full protection and security}

The CETA and FTA also follow the U.S. model on the related right of foreign investors to "full protection and security" by limiting the concept to the physical security of investors and

${ }^{6}$ CETA (n 2 above) Article X.9(2).

57 FTA (n 3 above) Article 9.4(3).

$5^{8}$ CETA (n 2 above) Article X.9(2)(f).

59 FTA (n 3 above) Article 9.4(2)(e).

6o CETA (n 2 above) Article X-9(4). 
investments. ${ }^{61}$ The CETA and FTA also include a clause, again consistent with the U.S. model, that precludes ISDS arbitrators from finding a breach of "full protection and security" or "fair and equitable treatment" based on a decision by the arbitrators that a country breached another provision in the trade agreement or a separate international agreement. ${ }^{62}$ The latter clause would seem unnecessary, except that some arbitrators have taken this remarkably expansive approach in past awards.

\section{Codification of an "umbrella clause"}

The FTA-but not the CETA-includes a type of "umbrella clause". That is, it incorporates other obligations of the host country into the foreign investor's rights under the FTA and thus subjects those other obligations to ISDS. In particular, the FTA states that a country must not "frustrate or undermine" a specific and clear commitment in a contractual obligation that is owed to a foreign investor. 63 This version of an umbrella clause is more limited than umbrella clauses in some other investment treaties, but it remains potentially very expansive in that it constitutes ISDS as a parallel system of enforcement for any contract concluded by the state.

This aspect of the FTA goes beyond the U.S. model, as reflected in NAFTA, which does not incorporate an umbrella clause. That said, many U.S. bilateral investment treaties include a broadly-worded umbrella clause. ${ }^{64}$ By going beyond the CETA, the FTA signals the Commission's willingness to accept this expansive aspect of foreign investor rights.

\section{Performance requirements}

A prohibition on performance requirements typically blocks countries from requiring foreign investors to use local goods or local suppliers, or to transfer technology, as potential conditions for being allowed to enter the country. The NAFTA prohibition on performance requirements, for example, has been used successfully by U.S. investors to resist research and development requirements in Canada's offshore oil sector. ${ }^{65}$

The U.S. model of ISDS includes an extensive prohibition on performance requirements and subjects that prohibition to ISDS and state-state enforcement. ${ }^{66}$ The CETA has a detailed prohibition on performance requirement, but subjects it to state-state enforcement only, not ISDS. ${ }^{67}$ In contrast, the FTA appears not to have any detailed prohibition on performance requirements. Thus, the CETA-in comparison to the FTA-tracks more closely the U.S. model on this issue but does not go all the way to adopting the U.S. model.

\footnotetext{
${ }^{61}$ CETA (n 2 above) Article X-9(5); FTA (n 3 above) Article 9.4(4).

62 CETA (n 2 above) Article X-9(6); FTA (n 3 above) Article 9.4(6).

63 FTA (n 3 above) Article 9.5(5).

64 K. Yannaca-Small, "Interpretation of the Umbrella Clause in Investment Agreements" in International Investment Law: Understanding Concepts and Tracking Innovations (Paris: OECD, 2008$) 115$.

65 Mobil Investments Canada Inc. and Murphy Oil Corporation $v$ Canada (Decision on Liability and Quantum [Public Version]) (22 May 2012).

66 e.g. NAFTA (n 15 above) Article 1106.

67 CETA (n 2 above) Article X.5.
} 


\section{National treatment}

As mentioned earlier, the CETA includes market access obligations. It does so by including the terms "establishment", "acquisition", and "expansion" in the list of foreign investment activities to which the CETA's national treatment obligation applies. ${ }^{68}$ The comparative list in the FTA is limited to post-establishment activities of foreign investors. ${ }^{69}$ Both agreements also have extensive reservations and schedules that carve out certain activities from the national treatment obligation. ${ }^{70} \mathrm{~A}$ comparative analysis of these reservations and schedules is beyond the scope of this paper.

\section{Market access}

On market access, the European Commission went further in its commitments in the CETA than in the FTA. However, it did not go as far in either agreement as the U.S. model would typically include, especially by subjecting market access obligations to ISDS. In the CETA, market access is linked to state-state enforcement processes only. In particular, market access is subject to detailed disciplines-derived from World Trade Organization (WTO) law-that are made enforceable through state-state dispute settlement but not ISDS. ${ }^{71}$ In contrast to the CETA, the FTA states that its investment chapter applies to investments "made... in accordance with the applicable laws", which is a conventional way to exclude market access from disciplines under the investment chapter. ${ }^{72}$

\section{Forum-shopping}

The CETA and the FTA take modest steps to limit forum-shopping. Both agreements allow an investor to bring a claim only if the investor has "substantial business operations" in the home state (i.e. in the jurisdiction of which the investor claims to be a national under the treaty). ${ }^{73}$ This is only a modest limitation on forum-shopping because it does not require the investor to have its headquarters or main base of operations in the home state. Thus, in both agreements, ISDS lawsuits have been facilitated for transnational corporations or individuals that have multiple individual or corporate nationalities. Either type of actor can bring an ISDS lawsuit under the relevant agreement if it has "substantial" business activities in one of the relevant jurisdictions, even if that jurisdiction is not their "home" or "dominant" jurisdiction.

\section{ISDS and financial services}

The CETA extends ISDS to the agreement's chapter on financial services, ${ }^{74}$ whereas the FTA does not. This extension leads to a complex interaction between the CETA's investment and

\footnotetext{
${ }^{68}$ CETA (n 2 above) Article X.6(1).

69 FTA (n 3 above) Article 9.3(1).

70 e.g. CETA (n 2 above) Article X.14; FTA (n 3 above) Article 9.3(2).

${ }^{71}$ CETA (n 2 above) Article X.4.

${ }^{72}$ FTA (n 3 above) Article 9(2)(1).

73 CETA (n 2 above) Article X.3.

74 CETA (n 2 above) Chapter 15 (Article 1(3) and (4)).
} 
financial services chapters. A close analysis of the interaction is beyond the scope of this paper. The essential point is that the CETA is similar to the U.S. model, which extends ISDS to its chapter on financial services, albeit to a lesser degree than the CETA. 75 As a result, the CETA clearly expands the obligations assumed by Canada in the regulation of financial institutions and services, by importing more obligations than NAFTA-such as fair and equitable treatment and full protection and security-from the investment chapter into the financial services chapter. ${ }^{76}$

10. Other foreign investor rights

The CETA and FTA contain a range of other foreign investor rights, including a right to generous compensation for losses 77 and expropriation ${ }^{78}$ and a right to make free capital transfers. ${ }^{79}$ The two deals do not vary markedly in this respect and the rights in question are also typical of the U.S. approach. One possibly significant variation is that a carve-out from the right to make free capital transfers in the FTA appears broader than the comparable carve-out in the CETA ${ }^{80}$ (and NAFTA $^{81}$ ) because, in the FTA, the carve-out includes exceptions on social security, public pensions, and taxation. ${ }^{82}$

\section{B. Provision for ISDS}

There are micro-level variations between the CETA and FTA in their approach to ISDS. However, these variations do not alter the overall assessment of the Commission's approach to ISDS on the criteria of independence, fairness, openness, and balance, as laid out earlier in this paper. Further, on nearly all key issues, the Commission's approach to ISDS tracks the U.S. model.

\section{Executive power over ISDS}

The CETA and FTA give key powers in ISDS to the Secretary-General of ICSID in Washington D.C. These powers include the critical power to appoint ISDS arbitrators when the disputing parties do not or fail to agree on an arbitrator, the power to appoint arbitrators outside of the roster set by the Parties to the agreement, and the power to decide all conflict of interest challenges against an arbitrator. ${ }^{83}$ The assignment of these powers to an executive official instead of a judicial actor is a key reason why ISDS does not to satisfy basic requirements of judicial independence. The assignment of these powers to the Secretary-General of ICSID follows the U.S. model and, on this issue, it demonstrates the Commission's willingness to accept U.S. evident preference in the allocation of executive power in ISDS.

\footnotetext{
75 NAFTA (n 15 above) Article 1401(2).

${ }^{76}$ CETA (n 2 above) Chapter 15 (Article 1(3) and (4)).

77 CETA (n 2 above) Article X.10; FTA (n 3 above) Article 9.5.

78 CETA (n 2 above) Article X.11; FTA (n 3 above) Article 9.6.

79 CETA (n 2 above) Article X.12; FTA (n 3 above) Article 9.7.

80 CETA (n 2 above) Article X.12(4).

${ }^{81}$ NAFTA (n 15 above) Article 1109(4).

82 FTA (n 3 above) Article 9.7(2).

83 CETA (n 2 above) Article X.25; FTA (n 3 above) Article 9.21.
} 


\section{Arbitrator expertise and experience}

The CETA and FTA limit the expertise or experience of ISDS arbitrators to the fields of public international law and, especially, "international investment law". The FTA requires arbitrators to have knowledge or experience in "the settlement of disputes under international investment agreements", 84 while the CETA states that it is "desirable" for arbitrators to have expertise or experience in international trade law and "the resolution of disputes arising under international investment or international trade agreements". 85

Thus, both agreements signal that future arbitrators will come from the existing "club" of arbitrators whose decisions have taken investment treaties in an investor-friendly direction since the late 1990s. If anything, the Commission's approach to ISDS signals an interest in protecting the role of the existing ISDS industry, based mainly in major law firms in the Western Europe and North America.

\section{Vetting of claims}

The CETA and FTA-once again, like the U.S. model-include a preliminary review mechanism to vet claims that are manifestly without legal merit ${ }^{86}$ or that are unfounded as a matter of law. ${ }^{87}$ Both agreements give this review role to the ISDS arbitrators, thus assigning the power to vet claims to decision-makers with a direct financial interest-because they are paid by the hour or day-in seeing the claim proceed.

\section{Cost shifting}

Unlike the U.S. model of ISDS, the CETA and the FTA provide for costs to be awarded to the losing side in ISDS. ${ }^{88}$ This provision would typically work in favour of the party that has more resources in the litigation because that party confronts less financial pressure associated with ISDS litigation. Thus, the provision appears to work in favour of large corporations and wealthy individuals relative to other foreign investors and many countries. It also appears to work in favour of large countries relative to small foreign investors and smaller countries.

\section{Other moderating language}

Again tracking the U.S. approach, the CETA and FTA have limiting provisions for the foreign investor right to compensation for expropriation. These provisions are essentially the same in both agreements. In the CETA, there is a significant risk that these limiting provisions will be undermined by the deal's approach to most-favoured-nation (MFN) treatment. The is a complex point, elaborated elsewhere. Essentially, in contrast to the FTA (which does not have a general

\footnotetext{
84 CETA (n 2 above) Article 9.21(6).

85 FTA (n 3 above) Article X.25(5).

86 CETA (n 2 above) Article X.29; FTA (n 3 above) Article 9.23.

87 CETA (n 2 above) Article X.30; FTA (n 3 above) Article 9.24.

88 CETA (n 2 above) Article X.36(5); FTA (n 3 above) Article 9.29.
} 
most-favoured-nation treatment clause in its investment chapter), the CETA uses qualified language when it purports to preclude the importation into the CETA-using the principle of MFN treatment-of additional substantive rights of foreign investors treaties with third states.

The CETA and the FTA also have special provisions on foreign investor rights and ISDS in the context of debt restructuring or a monetary crisis. ${ }^{89}$ These provisions are complex and a comparative analysis of them is beyond the scope of this paper. A general issue is that both deals continue to subject sovereign decisions during a financial crisis to review by ISDS arbitrators, albeit it to varying degrees.

\section{Statements of interpretation}

Again following the U.S. model, the CETA and FTA allow for the Parties (i.e. states parties) to the agreement to issue interpretations of the agreement that are binding on arbitrators. ${ }^{\circ 0}$ This device is potentially useful to rein in arbitrator adventurism; that said, the device has been available for over 20 years under NAFTA and has only been used twice..$^{91}$ On that basis, it should not be considered a significant limitation on arbitrator power. As discussed earlier in this paper, other aspects of the CETA and FTA indicate that the Commission is quite content with the ISDS arbitrators' expansive approaches to foreign investor rights, especially with respect to legitimate expectations as an expansive component of fair and equitable treatment.

\section{Acknowledgement of regulatory chill}

There is a notable variation from the U.S. approach in the CETA but not the FTA. The CETA's provision on the arbitrators' power to award damages to foreign investors includes a clause that I have not seen in any investment treaty. The clause says that, in calculating monetary damages, the arbitrators shall reduce the damages to account for "any... repeal or modification of the measure". ${ }^{92}$ Thus, the CETA appears to establish an incentive for states to change their decisions in order to appease a foreign investor (who has brought an ISDS claim) as a means to limit the state's exposure to potentially massive liability at the hands of the arbitrators. Put differently, this clause in the CETA appears to institutionalize the ISDS dynamic of "regulatory chill". That said, compared to the chilling pressure that ISDS can bring to bear on states in general, this aspect of the CETA seems to be more an acknowledgement than a significant exacerbation of the pressure.

\section{Survival clause}

The CETA and FTA include a survival clause-which extends the agreements' protections for foreign investors in the event of termination of the agreement.93 Also, neither of the agreements allows for termination of its investment chapter, or its provisions on ISDS, separately form the

89 CETA (n 2 above) Annex X; FTA (n 3 above) Articles 9.7(3) and 17.9.

${ }^{90}$ CETA (n 2 above) Article X.27(2); FTA (n 3 above) Article 9.22(3).

${ }^{91}$ Free Trade Commission (n 24 above).

92 CETA (n 2 above) Article X.36(3).

93 CETA (n 2 above) Article X.o8(2); FTA (n 3 above) Article 9.9. 
overall trade agreement. Thus, significant economic and political costs would be attached to any future decision to pull out of ISDS once the agreement has been ratified and put into force.

This approach to locking in ISDS commitments, by making them part of a larger trade agreement, is new in the European context, which previously limited ISDS to bilateral investment treaties that can be terminated without affecting trade commitments. The approach based on embedding of ISDS in a trade agreement reflects the U.S. model.

The survival clauses and informal lock-ins are particularly anti-democratic aspects of ISDS, albeit typical to the European and U.S. model since the 1970s. These aspects are atypical in the CETA and potentially the TTIP in that that they are being extended, beyond NAFTA, to relations among developed countries.

\section{Conclusion}

The CETA and FTA demonstrate the Commission's willingness to accept ISDS-based on the model long pushed by Western European countries for developing and transition countriesthat is flawed due to its lack of independence, fairness, and balance. The Commission's approach to ISDS, as represented by the CETA and FTA, does not ensure basic safeguards of judicial independence and procedural fairness. It does not affirm clearly the state's right to regulate. It does not introduce actionable responsibilities for foreign investors or even require foreign investors to resort to domestic courts unless they have been shown not to offer justice. The only notable improvement in the CETA and FTA approach to ISDS, compared to the historical Western European model, is its greater provision for openness.

A micro-level assessment of the CETA and FTA text highlighted some variations between the two agreements that raised uncertainties about the Commission's actually preferred approach. Yet, overwhelmingly, the micro-level assessment demonstrated the Commission's willingness to accept the U.S. model of ISDS. Most importantly, the assessment did not affect the overall conclusion $\mathrm{n}$ that the Commission has endorsed an ISDS model that does not satisfy basic criteria of independence, fairness, and balance.

By including ISDS in the CETA and FTA, as forerunners of a TTIP, the Commission would make the problems of ISDS much worse. The Commission aims to expand and lock in a deeply flawed system of dispute resolution-premised on the special privileging and subsidizing of large companies and very wealthy individuals, with lucrative returns also for ISDS lawyers and arbitrators-so that it covers most of the world economy. 